\title{
WYBRANE ASPEKTY OPIEKI NAD DZIECKIEM Z PĘCHERZEM NEUROGENNYM I PRZETOKA MITROFANOFFA
}

\section{SELECTED ASPECTS OF CARE OF THE CHILD WITH THE NEUROGENIC BLADDER AND MITROFANOFF STOMA}

\author{
Gruszka Martyna, a, 2 , Kudela Grzegorz², b , Koszucki Tomasz ${ }^{2, c}$ \\ ${ }^{1}$ Studium doktoranckie, Wydział Nauk o Zdrowiu, Śląski Uniwersytet Medyczny w Katowicach \\ ${ }^{2}$ Klinika Chirurgii i Urologii Dziecięcej, Górnośląskie Centrum Zdrowia Dziecka im. Jana Pawła II w Katowicach
}

${ }^{a}$ https://orcid.org/0000-0001-8574-9325

${ }^{\mathrm{b}}$ https://orcid.org/0000-0001-6743-9833

${ }^{c}$ https://orcid.org/0000-0001-6110-6640

DOI: https://doi.org/10.20883/pielpol.2019.41

\section{STRESZCZENIE}

Wstęp. Zaburzenia w oddawaniu moczu oraz stolca są wiodącymi problemami wielospecjalistycznej opiece nad dzieckiem z zespołem dystrofii. Opracowano szereg metod umożliwiających sprawne opróżnianie neurogennego pęcherza moczowego. Najczęściej stosowana jest metoda CIC (Clean Intermittent Catheterisation), jej regularne stosowanie skutkują ochroną górnych dróg moczowych oraz zmniejszeniem częstości zakażeń układu moczowego. Ułatwieniem dla pacjentów z zachowana sprawnościa kończyn górnych jest cewnikowanie przez przetokę Mitrofanoffa. Istotne jest przestrzeganie regularności, aseptyki zabiegów, z jednoczesnym nadzorowaniem opróżniania jelit.

Cel. Celem pracy było przedstawienie problematyki opieki nad dzieckiem z pęcherzem neurogennym i przetoką Mitrofanoffa. Materiał i metody. Materiał pracy stanowi przegląd aktualnej literatury medycznej oraz obserwacje własne autora.

Wnioski. Dzięki wytworzeniu szczelnych przetok moczowych i holistycznej opiece u dzieci z neurogennymi zaburzeniami pęcherza możemy sprawniej kontrolować proces wydalania moczu, a tym samym zapobiegać uszkodzeniu górnych dróg moczowych i dążyć do poprawy jakości życia dzieci i ich opiekunów.

SŁOWA KLUCZOWE: opieka, pęcherz neurogenny, przetoka Mitrofanoffa.

\section{Wstęp}

Osiągnięcie umiejętności kontrolowanego oddawania moczu jest procesem stopniowym, związanym z dojrzewaniem struktur centralnego i obwodowego układu nerwowego. W procesie rozwoju dziecka coraz wyższe piętra układu nerwowego przejmują kontrolę nad czynnością mięśnia wypieracza i zwieracza cewki moczowej [1].

\begin{abstract}
Introduction. Disorders in passing urine and stool are the leading problems of multidisciplinary care for a child with a dystrophic syndrome. A number of methods have been developed to allow efficient emptying of the neurogenic bladder. The most common method is the $\mathrm{CIC}$ (Clean Intermittent Catheterization) method, its regular use results in the protection of the upper urinary tract and reduces the incidence of urinary tract infections. The Mitrofanoff catheter is a facilitation for patients with preserved upper limb performance. It is important to observe regularity, aseptic of treatments, while monitoring the emptying of the intestines.

Aim. The aim of the study was to present the problems of care for a child with a neurogenic bladder and Mitrofanoff fistula.

Material and methods. The material of the study is an overview of current medical literature and author's own observations.

Conclusions. Thanks to the creation of tight urinary fistulas and holistic care, children with neurogenic bladder disorders can more efficiently control the process of urinary excretion, and thus prevent damage to the upper urinary tract.
\end{abstract}

KEYWORDS: care, neurogenic bladder, Mitrofanoff stoma.

Zaburzenia mikcji dotyczą zarówno dzieci z prawidłowo rozwiniętym układem nerwowym, jak i tych z neurogenną dysfunkcją pęcherza. Jak podaje piśmiennictwo, około $25 \%$ klinicznych problemów spotykanych w urologii dziecięcej jest wynikiem uszkodzenia układu nerwowego [2]. W wadach dystroficznych dochodzi do zaburzeń w przewodnictwie dróg wstępujących i zstępujących łączących pęcherz moczowy z wyższymi pię- 
trami układu moczowego. W wyniku tych właśnie zaburzeń dochodzi do nieprawidłowej pracy wypieracza lub/i zwieracza, wzrostu ciśnienia śródpęcherzowego i ciśnienia mikcji. Zalegający mocz ulega zakażeniom, stąd tak ważne jest zapewnienie efektywnego odpływu moczu u tych chorych. Uszkodzenie układu nerwowego zaburza czucie wypełniania pęcherza, odczuwanie potrzeby oddania moczu, tym samym powodując nietrzymanie moczu lub/i bezwiedne, nieregularne jego oddawanie. Innym problemem jest m.in. niecałkowite opróżnianie pęcherza moczowego na skutek nadmiernie napiętego zwieracza cewki lub jego nadreaktywność z powodu wysokiego ciśnienia śródpęcherzowego.

Do najbardziej charakterystycznych postaci zaburzeń oddawania moczu należy: częste parcie na mocz, częstomocz, popuszczanie i całkowite nietrzymanie moczu, zaleganie moczu po mikcji oraz ból podczas oddawania moczu lub całkowita niemożność oddania moczu, z wyczuwalnym w badaniu palpacyjnym przepełniony pęcherzem moczowym. Zasadniczym celem leczenia dysfunkcji neurogennych dróg moczowych jest uchronienie górnych dróg moczowych przed ich postępującym uszkodzeniem [1-5]. Cel ten można osiągnąć poprzez: utrzymanie niskiego ciśnienia środpęcherzowego $w$ fazie gromadzenia i wydalania moczu, skuteczne opróżnianie pęcherza, zapobieganie zakażeniom, a także zapewnienie tzw. socjalnego trzymania moczu. Wybór postepowania terapeutycznego zależy od rodzaju stwierdzonej dysfunkcji dróg moczowych, doświadczenia zespołu sprawującego opiekę nad dzieckiem oraz metod, którymi dysponuje.

\section{Metody umożliwiające efektywne opróżnianie pęcherza moczowego w warunkach jego neurogenności}

\section{Clean Intermittent Catheterisation (CIC)}

Dawniej, by opróżnić pęcherz u pacjentów z neurogenną dysfunkcją dolnych dróg moczowych, stosowano m.in. zabieg Credego (Valsalvy), tzw. bladder exression (opukiwanie powłoki brzusznych), co powodowało niebezpieczny wzrost ciśnienia w pęcherzu, które negatywnie wpływa na prace górnego układu moczowego $[1,6]$. Dlatego też metody tej zaniechano, a obecnie podstawowym działaniem leczniczym przy neurogennej dysfunkcji pęcherza powinno być dążenie do całkowitego jego opróżnienia, bez zalegań i w sposób jak najbardziej niskociśnieniowy. Metodą zapewniająca takie odprowadzenie moczu jest jego opróżnianie za pomocą cewnikowania przerywanego, nazywanego powszechnie samocewnikowaniem. CIC (Clean Intermittent Catheterisation), czyli niskociśnieniowa metoda odprowadzenia moczu z pęcherza moczowego przeprowadzana jest przy użyciu jednorazowych cewników z miękkiego i elastycznego materiału PVC, np. typu Nelaton, które są refundowane, a dostęp do nich bardzo ułatwiony. Okresowe cewnikowanie pęcherza moczowego wprowadził w 1972 roku J. Lapides u pacjentów z neurogenną dysfunkcją układu moczowego [6-8]. Podczas wykonywania omawianej procedury należy pamiętać o zasadach aseptyki i użyciu cewników w rozmiarze dopasowanym indywidualnie do warunków fizjologicznych dziecka, co kilka godzin odprowadzając objętość moczu zbliżoną do naturalnej mikcji [9]. Zabezpieczenie dziecka w porze nocnej, gdy ta metoda odprowadzenia moczu jest ograniczona z powodu snu, można uzyskać przez założenie cewnika i podłączenie go do worka zbiorczego tzw. otwartego cewnika Foleya. Jednak, jak wskazuje w swojej pracy Zajda J., ten model odprowadzenia moczu jest nadużywany przez opiekunów dzieci z opisywani problemami i po czasie prowadzi m.in. do powstawania odleżyn czy marskości pęcherza na skutek trwałego ucisku [10]. Ponadto, jak wiadomo, cewnik Foleya jest źródłem wielu infekcji układu moczowego. Dlatego też nigdy nie powinno wypełniać się balona cewnika 0,9\% $\mathrm{NaCl}$, co jest źródłem odkładania się substancji organicznych, które mogą być przyczyną występowania złogów w pęcherzu. W tym przypadku zaleca się stosowanie m.in. obojętnej wody do wstrzyknięć. Kolejnym czynnikiem, który wpływa na częste zakażenia układu moczowego u dzieci, są zalegania moczu w pęcherzu lub/i nietrzymania moczu skutkującego długotrwałym przebywaniem w mokrej pieluszce. Dlatego tak ważna w przypadku stosowania CIC jest profilaktyka zakażeń układu moczowego. W tym celu wprowadza się obfite pojenie dziecka, leki o działaniu odkażającym, np. furagin, zioła, preparaty zawierające żurawinę i płukanie pęcherza m.in. azotanem srebra (AgNO3) w rozcieńczeniu 1/1000 i preparatami roślinnymi oraz leczenie owsicy i zaparć $[2,11]$.

\section{Przetoka Mitrofanoffa}

Niewątpliwie dużym problemem jest cewnikowanie najmłodszych w trakcie zajęć szkolnych czy przedszkolnych. Ważne w tym okresie jest rozmowa z opiekunem i uświadomienie go, iż proces nauki samodzielnego cewnikowania się dziecka można rozpocząć już w 7. roku życia. Większość dzieci z zachowaną sprawnością intelektualną i manualną chętnie uczestniczy w procesie nauki CIC. Jednak dla dzieci z ograniczeniami w obrębie kręgosłupa czy poruszających się na wózkach inwalidzkich może to stanowić ogromny problem, nie tylko z powodu braku ruchomości w poszczególnych stawach, które umożliwiałoby samodzielne cewnikowanie przez cewkę moczowa, ale także z powodu spędzania większości czasu w pozycji siedzącej. Przeszkodę 
stanowić może również np. zwężenia cewki moczowej u dziewczynek. Dlatego też wciąż udoskonalane są metody chirurgiczne zmierzające do wytworzenia takiej przetoki, która bezpiecznie i łatwo pozwoli odprowadzić mocz u każdego pacjenta. Niewątpliwie skuteczną próbą wytworzenia możliwie prostej i funkcjonalnej przetoki jest sposób Mitrofanoffa, który został opisany w 1980 roku. Metoda ta wykorzystuje wyrostek robaczkowy jako kanał między pęcherzem moczowym a powłokami skórnymi [12-13]. Stosowana jest u dzieci z neurogenną dysfunkcją pęcherza związaną z przepukliną oponowordzeniową, rozszczepem kręgosłupa lub wadami anatomicznymi. Zaletą tej metody jest umożliwienie cewnikowania przerywanego u pacjentów z przeciwskazaniami do cewnikowania drogą fizjologiczna, łatwiejsze odprowadzenie moczu niż w przypadku cewnikowania przez cewkę, w związku z możliwością wprowadzenia cewnika przez powłoki brzuszne w pozycji siedzącej, czy samodzielne wykonanie tej procedury przez dzieci z porażeniem kończyn dolnych a zachowaną sprawnością intelektualną. Zaletą jest także wytworzenie sprawnego mechanizmu zastawkowego, który ogranicza wypływanie moczu na powłoki brzuszne, ograniczając przykry zapach i dyskomfort dziecka. Wykorzystanie do tej techniki m.in. jajowodu, nasieniowodu lub fragmentu żołądka nie zyskało uznania [14]. Jak obrazuje praca Chaviano i wsp., wszystkie dzieci biorące udział w badaniu, po zabiegu wyłonienia przetoki Mitrofanoffa uzyskały samodzielność w procesie cewnikowania, a średni czas poświęcony tej czynności zmniejszył się o prawie 11 minut w ciągu dnia. Poziom satysfakcji z procesu odprowadzenia moczu również znacząco wzrósł z 2,3/5 punktów w skali przed wykonaniem zabiegu do 4,5/5 punktów po zabiegu [13]. Mimo niepodważalnych zalet, metoda ta znacznie ogranicza zmiany pozycji ciała, a cała procedura wykonywana jest najczęściej w pozycji siedzącej w wózku inwalidzkim. Z obserwacji własnych wynika, że u dzieci z przetoką Mitrofanoffa ta właśnie pozycja sprzyja tworzeniu odleżyny w okolicy pośladkowej i kości krzyżowej.

\section{Farmakoterapia}

W przypadku zaburzeń funkcji wydalniczej układu moczowego szybkie wdrożenie leczenia oraz indywidualne podejście do pacjenta jest jedyną sprawdzoną metodą zapobiegania powikłaniom. Leczeniem z wyboru w neurogennej dysfunkcji pęcherza jest zastosowanie leków m.in. antycholinergicznych, ostrzyknięcie toksyną botulinową pęcherza czy sfinkterotomia (chirurgiczne przecięcie dolnego zwieracza). U licznej grupy pacjentów istnieje możliwość poprawy funkcji pęcherza przez zastosowanie doustnych inhibitorów receptora $\alpha$-adrenergicznego, np. doksazosyny, terazosyny.
Farmakoterapię można poszerzyć także o leki z grupy $\alpha$-andrenomimetyków, np. efedrynę, powodującą wzrost napięcia zwieracza wewnętrznego. Ten rodzaj leczenia niesie jednak wiele objawów niepożądanych w postaci zaburzenia snu i rytmu serca. Lekami najczęściej stosowanymi u dzieci z pęcherzem neurogennym są leki antycholinergiczne wykazujące korzystne działanie w nadczynności wypieracza $[1,2,5]$.

\section{Uroterpia}

Uroterapia, czyli leczenie dolnych dróg moczowych metodami niefarmakologicznymi (niechirurgicznymi), w leczeniu czynnościowych zaburzeń mikcji ma aż 42\% skuteczności [15]. Jednak na próżno szukać w literaturze potwierdzenia skuteczności stosowania metod elektrostymulacji pęcherza czy terapii behawioralnej w przypadku dzieci z neurogenną dysfunkcją dróg moczowych.

\section{Leczenie zaparć}

Czynnikiem, który wpływa równie niekorzystnie na opróżnianie pęcherza, są częste zakażenia układu moczowego oraz zaparcia, które podrażniają ścianę pęcherza moczowego i wywierają ucisk na cewkę moczową, co utrudnia całkowite opróżnianie pęcherza. Dochodzi wtedy do nadmiernego wypełnienia pęcherza i wyciekania moczu z przepełnienia. Przyczyną zaparć jest neurogenne jelito oraz najczęściej zła dieta uboga w błonnik. Dlatego też opiekunom dzieci z opisywanymi problemami zaleca się prowadzenie zbilansowanej diety oraz codzienne wykonanie wlewów czyszczących z wykorzystaniem np. enemy. W skrajnie trudnych przypadkach rozważyć należy założenie przetoki Malone’a.

\section{Wybrane problemy codziennej opieki pielęgniarskiej nad dzieckiem z neurogenną dysfunkcją pęcherza moczowego w zespole dystroficznym}

Zaburzenia w oddawaniu moczu stanowią złożony i częsty problem w praktyce pediatrycznej i urologicznej, ale są także dużym wyzwaniem dla osób sprawujących opiekę nad dzieckiem, zarówno w zakresie pielęgnacji, realizacji zaleceń lekarskich i edukacji małego pacjenta.

W opiece nad dzieckiem z neurologicznymi zaburzeniami układu moczowego należy wykazać się indywidualnym podejściem opartym na wywiadzie rodzinnym i środowiskowym. Nigdy też nie należy zapomnieć o szczególnej dokładności, delikatności i poszanowaniu intymności dziecka podczas wykonywania czynności pielęgnacyjnych. Często niezauważone odpowiednio wcześnie zmiany skórne na skutek złej pielęgnacji czy 
urazów mogą doprowadzić do odleżyn. Dzieci z opisywanymi problemami wymagają pomocy przy toalecie ciała, zmianie bielizny osobistej i pościelowej. Codzienną toaletę ciała w łóżku bądź wannie, z użyciem niedrażniących środków, należy wykonywać minimum dwa razy dziennie. Skórę dziecka po kąpieli należy zawsze nawilżać i natłuszczać. Większość dzieci, które pod względem intelektualnym rozwijają się prawidłowo, a funkcja kończyn górnych jest zachowana, bardzo chętnie uczestniczy w czynnościach pielęgnacyjnych. Kolejnym wyzwaniem w opiece nad dzieckiem jest przeciwdziałanie powstawaniu odparzeń w pachwinach i na pośladkach. Do tego typu niekorzystnych zmian dochodzi najczęściej u dzieci popuszczających mocz i tych ze znacznym rozciągnięciem zwieracza odbytu, skutkiem czego są niekontrolowane wypadanie kamieni kałowych i brudzenie bielizny. By temu zapobiec, należy wymieniać pieluchy jednorazowe zawsze według potrzeby, starannie myć i osuszać pachwiny lub w przypadku wystąpienia zaczerwienienia zastosować antyseptyczne kremy bądź zasypki. Ważnym elementem w opiece nad dzieckiem z omawianym problemem jest obserwacja ilości przyjmowanych płynów, ich zmniejszona ilość może prowadzić do zakażeń układu moczowego, stanów zapalnych przedsionka pochwy u dziewczynek, zaparć czy nawet zaburzeń neuropsychiatrycznych, np. zaburzeń snu. Niektórzy autorzy zalecają, by spożywane płyny przez dzieci kontrolować i zapisywać. Rodzice powinni być poinstruowani, że płyny zawierające kofeinę powinny być stosowane jedynie rano i popołudniu, zalecane soki naturalne z wysoką zawartością witaminy $C$, wodę należy spożywać natomiast bez ograniczeń. By łatwo odmierzać ilość przyjętych przez dzieci płynów, można porcjować je w $500 \mathrm{ml}$ butelkach. Można przyjąć, że ostatnia porcja płynów powinna być podana dziecku ok. 2 h przed snem. Często pomijanym, a jakże ważnym elementem w opiece nad dzieckiem, jest także przedstawienie najmłodszym prawidłowej budowy układu moczowego, w sposób odpowiedni do wieku. Często u dzieci młodszych stosuje się porównania napełnionego pęcherza do balona czy przepełnionej miski z woda. Z kolei ważną informacją dla opiekunów dzieci z wyłonioną przetoką Mitrofanoffa jest fakt, że w przypadku braku cewnikowania przez przetoke, stomia ta zarasta uniemożliwiając prawidłowe działanie. Dlatego też sumienność, dokładność w procesie cewnikowania przez przetokę jest bardzo istotna. Opiekun może stosować metodę budzika, by w sposób dźwiękowy sygnalizować potrzebę cewnikowania i odprowadzenia moczu z pęcherza. Okolice przetoki należy obserwować w kierunku ew. cech infekcji, a okolice skóry osuszać, a w przypadku podrażnień - natłuszczać, bądź sto- sować opatrunki specjalistyczne z wysokim stopniem uwodnienia. Toaleta codzienna w okolicy przetoki po zagojeniu samej rany pooperacyjnej powinna odbywać się m.in. raz dziennie przy użyciu mydła antybakteryjnego i miękkich ręczników do osuszania okolicy przetoki.

\section{Podsumowanie}

Dzięki wytworzeniu szczelnych przetok moczowych i holistycznej opiece, dzieci z neurogennymi zaburzeniami pęcherza mogą sprawniej kontrolować proces wydalania moczu, co zapobiega również odległym następstwom choroby, m.in. uszkodzeniu górnych dróg moczowych. Integralną częścią opieki nad chorym jest również kontrola i pomoc w sprawnym opróżnianiu jelit i wydalaniu stolca. Tak sprawowana opieka przyczynia się do lepszego funkcjonowania dziecka w środowisku rówieśniczym, umożliwiając mu uczestnictwo w wielu aktywnościach i ograniczając tym samym skutki niepełnosprawności.

\section{Piśmiennictwo}

1. Borkowski A. Red. Urologia: Podręcznik dla studentów medycyny. PZWL; Warszawa 2015, wyd. II.

2. Skobejko-Włodarska L. Neurogenna dysfunkcja pęcherzowo-cewkowa u dzieci. Prz. Urol 2015; 3 (91): 14.

3. Apoznański W. Następstwa augmentacji pęcherza moczowego u dzieci - powikłania i konsekwencje. Clin.Exp Med 2005; 14 (6): 1307-1312.

4. Apoznański W. Neurogenic Voiding Dysfunction in Children - Reasons, Classification, Treatmen. Clin Exp Med 2005; 14 (2): 309-314.

5. Kulik-Rechbrger B, Miotła P, Rechberger T. Leczenie zaburzeń funkcjonowania dolnych dróg moczowych w przebiegu wybranych schorzeń neurologicznych u dzieci i dorosłych. Toksyna botulinowa jako nowa obiecująca opcja lecznicza dysfunkcji pęcherza moczowego w schorzeniach neurologicznych. Forum Med Rodz 2013;7(4): 215-224.

6. Zajda J. Pacjent z neurogenną dysfunkcją pęcherza. Prz. Urol 2012; 1 (71).

7. Hatice K, Gülsün ÖA. An Important Problem for the Individuals with Spinal Cord Injury: Neurogenic Bladder. JNNN 2015;4(1):35-39.

8. Lapides J, Diokno A, Silber SJ. Clean Intermittent self Catheterization in the treatment of urinary tract disease. J Urol 1972; 107: 58-61.

9. de Jong TPVM, Aart J. Klijn, Dik P. Treatment of the neurogenic bladder in spina bifida. Pediatr Nephrol 2008; 23:889-896.

10. Zajda J. Pacjent z neurogenna dysfunkcja pęcherza. Praktyka ambulatoryjna. Prz. Urol 2012/1 (71).

11. Bochniewska V, Jung A, Żuber J. Zakażenie układu moczowego u dzieci. Pediatr Med. Rodz 2012; 8 (1): 12-22.

12. Berkowitz J, North AC, Tripp R, Gearhart JR. Lakshmanan Y. Mitrofanoff continent catheterizable conduits: Top down or bottom up? J Pediatr Urol. 2009( 5):122-125.

13. Mallikarjun N Reddy, Rajendra B Nerli, Ranjeet A Patil, Sujata MJ. Laparoscopic Mitrofanoff continent catheterisa- 
ble stoma in children with spina bifida; Afr J Paediatr Surg 2015;12(2):126-30.

14. Levy ME, Elliott SE. Reconstructive techniques for creation of catheterizable channels: tunneled and nipple valve channels. Transl Androl Urol. 2016;5(1):136-144.

15. Carretero SF i wsp. The role of urotherapy in the management of urinary incontinence. Acta Pediatr Esp. 2012; 70(8): 322-325.

Artykuł przyjęty do redakcji: 02.10.2018.

Artykuł przyjęty do publikacji: 31.02.2019.
Źródło finansowania: Praca nie jest finansowana z żadnego źródła. Konflikt interesów: Autorzy deklarują brak konfliktu interesów.

\section{Adres do korespondencji:}

Martyna Gruszka

Klinika Chirurgii i Urologii Dziecięcej, Górnośląskie Centrum Zdrowia Dziecka im. Jana Pawła II w Katowicach

ul. Medyków 16

40-752 Katowice

tel.: 32 20717-50

e-mail: gruszkaa.martyna@gmail.com 